\title{
STABILITY INDICATING METHOD DEVELOPMENT AND VALIDATION OF MITOMYCIN AND FLUOROURACIL BY USING UPLC
}

\section{GUNTURU RAVITEJA ${ }^{*}$, KANTIPUDI RAMBABU ${ }^{2}$}

\author{
${ }^{* 1,2}$ Department of Chemistry, RVR and JC College of Engineering, Chowdavaram, Guntur 522019, Andhra Pradesh, India \\ Email: gravitejascholar84@gmail.com
}

Received: 21 Jun 2021, Revised and Accepted: 28 Jul 2021

\begin{abstract}
Objective: The current investigation was pointed at developing and progressively validating novel, simple, responsive and stable UPLC method for the measurement of active pharmaceutical ingredients of Mitomycin and Fluorouracil.

Methods: A simple, selective, validated and well-defined stability that shows isocratic UPLC methodology for the quantitative determination of Mitomycin and Fluorouracil. The chromatographic strategy utilized Inertsil ODS column of dimensions $250 \times 4.6$ mm, 5 micron, using isocratic elution with a mobile phase of acetonitrile and 0.1 percent formic acid (70:30). A flow rate of $1 \mathrm{ml} / \mathrm{min}$ and a detector wavelength of $255 \mathrm{~nm}$ utilizing the PDA detector was given in the instrumental settings. Validation of the proposed method was carried out according to an international conference on harmonization (ICH) guidelines.
\end{abstract}

Results: LOD and LOQ for the two active ingredients were established with respect to test concentration. The calibration charts plotted were linear with a regression coefficient of $\mathrm{R}^{2}>0.999$, means the linearity was within the limit. Recovery, specificity, linearity, accuracy, robustness, ruggedness were determined as a part of method validation and the results were found to be within the acceptable range.

Conclusion: The proposed method to be fast, simple, feasible and affordable in assay condition. During stability tests, it can be used for routine analysis of production samples and to verify the quality of drug samples during stability studies.

Keywords: Mitomycin, Fluorouracil, UPLC, Development, Validation

(C) 2021 The Authors. Published by Innovare Academic Sciences Pvt Ltd. This is an open-access article under the CC BY license (https://creativecommons.org/licenses/by/4.0/] DOI: https://dx.doi.org/10.22159/ijap.2021v13i5.42490. Journal homepage: https://innovareacademics.in/journals/index.php/ijap

\section{INTRODUCTION}

The mitomycins are a family of aziridine-containing natural products isolated from Streptomyces caespitosus or Streptomyces lavendulae $[1,2]$. They include mitomycin A, mitomycin B, and mitomycin $\mathrm{C}$. When the name mitomycin occurs alone, it usually refers to mitomycin $\mathrm{C}$, its international nonproprietary name. Mitomycin C is used as a medicine [3] for treating various disorders associated with the growth and spread of cells. In the bacterium Legionella pneumophila [4-6], mitomycin C induces competence for transformation [7] Natural transformation is a process of DNA transfer $[8,9]$ between cells and is regarded as a form of bacterial sexual interaction. In the fruit fly Drosophila melanogaster $[10,11]$, exposure to mitomycin $C$ increases recombination during meiosis $[12,13]$, a key stage of the sexual cycle [14]. In the plant Arabidopsis thaliana $[15,16]$, mutant strains defective in genes necessary for recombination during meiosis and mitosis [17, 18] are hypersensitive to killing by mitomycin C [19]. Mitomycin $\mathrm{C}$ has been shown to have activity against stationary phase persisters caused by Borrelia burgdorferi, a factor in lyme disease $[20,21]$. Mitomycin $\mathrm{C}$ is used to treat symptoms of pancreatic and stomach cancer and is under clinical research for its potential to treat gastrointestinal strictures [22], wound healing from glaucoma surgery [23] corneal excimer laser surgery [24] and endoscopic dacryocystorhinostomy [25].

Fluorouracil (5-FU), sold under the brand name Adrucil among others, is a medication used to treat cancer [26]. By injection into a vein it is used for colon cancer [27], esophageal cancer [28], stomach cancer, pancreatic cancer [29], breast cancer [30], and cervical cancer [31]. As a cream, it is used for actinic keratosis [32], basal cell carcinoma [33], and skin warts [34]. When used by injection, most people develop side effects. Common side effects include inflammation of the mouth, loss of appetite, low blood cell counts, hair loss, and inflammation of the skin. When used as a cream, irritation at the site of application usually occurs. Use of either form in pregnancy may harm the baby. Fluorouracil is in the antimetabolite [35] and pyrimidine analog families of medications. How it works is not entirely clear but believed to involve blocking the action of thymidylate synthase [36] and thus stopping the production of DNA. It is on the World Health Organization's List of Essential Medicines, the safest and most effective medicines needed in a health system [37]. Fluorouracil has been given systemically for anal, breast, colorectal, oesophageal, stomach, pancreatic and skin cancers (especially head and neck cancers). It has also been given topically (on the skin) for actinic keratoses, skin cancers and Bowen's disease [38] and as eye drops for the treatment of ocular surface squamous neoplasia. Other uses include ocular injections into a previously created trabeculectomy [39] bleb to inhibit healing and cause scarring of tissue, thus allowing adequate aqueous humor flow to reduce intraocular pressure [40]. The present study aims the development and validation of Mitomycin and Fluorouracil using UPLC.

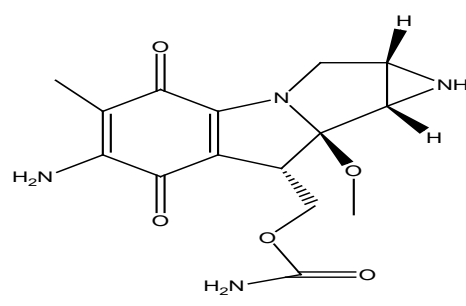

A<smiles>O=c1[nH]cc(F)c(=O)[nH]1</smiles>

B
Fig. 1: Structure of (A) Mitomycin and (B) Fluorouracil

\section{MATERIALS AND METHODS}

\section{Chemicals}

Acetonitrile (HPLC grade), formic acid, water (HPLC grade), were purchased from Merck India Ltd, Mumbai, India. APIs of Mitomycin, Fluorouracil standards were procured from Glen mark, Mumbai. 


\section{The instrumentation}

Waters Acquity model UPLC with quaternary pump, PDA detector with empower 2.0 software was used [41].

\section{Preparation of buffer}

$1 \mathrm{ml}$ of formic acid is dissolved in $1 \mathrm{~L}$ of HPLC grade water and filter through $0.45 \mu$ filter paper.

\section{Chromatographic conditions}

The analysis was performed on reverse phase UPLC system with isocratic elution mode using a mobile phase of acetonitrile and $0.1 \%$ formic acid (70:30) and Inertsil ODS column $(250 \times 4.6 \mathrm{~mm}, 5 \mu)$ column with a flow rate of $1 \mathrm{ml} / \mathrm{min}$.

\section{Diluent}

Water and Acetonitrile in the ratio (50:50) is used as diluent.

\section{Validation procedure}

The analytical parameters such as system suitability, precision, specificity, accuracy, linearity, robustness, LOD, LOQ, forced degradation and stability were validated according to ICH Q2 (R1) guidelines [42-47].

\section{Preparation of the standard stock solution}

For standard stock solution preparation, add $70 \mathrm{ml}$ of diluents to $100 \mathrm{mg}$ of Mitomycin and $100 \mathrm{mg}$ of Fluorouracil taken in a $100 \mathrm{ml}$ volumetric flask and sonicate for $10 \mathrm{~min}$ to fully dissolve the contents and then makeup to the mark with diluent.

\section{Preparation of standard solution}

$1 \mathrm{ml}$ of solution is drawn from the above normal stock solution into a $10 \mathrm{ml}$ volumetric flask and diluted up to the level.

\section{Preparation of sample solution}

Take $130 \mathrm{mg}$ of the sample drug Mitomycin and $100 \mathrm{mg}$ of the sample drug Fluorouracil into a $100 \mathrm{ml}$ volumetric flask and add 70 $\mathrm{ml}$ of diluents and sonicate for $10 \mathrm{~min}$ to fully dissolve the contents and then make up the mark with diluent. This solution is filtered into a device using a $0.45 \mu$ nylon syringe in a vial.

\section{RESULTS AND DISCUSSION}

The main analytical challenge during development of a new method was to separate active Pharma ingredients. In order to provide a good performance the chromatographic conditions were optimized.

\section{Method optimization}

To optimize the chromatographic conditions, different ratios of phosphate buffer and the acetonitrile in the mobile phase with isocratic and gradient mode was tested. However, the mobile phase composition was modified at each trial to enhance the resolution and also to achieve acceptable retention times. Finally, $0.1 \%$ formic acid buffer and acetonitrile with isocractic elution was selected because it results in a greater response of active pharmacy ingredients. During the optimization of the method, various stationary phases such as $\mathrm{C}_{8}, \mathrm{C}_{18}$ phenyl and amino, inertsil ODS columns were tested. From these trials the peak shapes were relatively good with a inertsil ODS column of $250 \times 4.6 \mathrm{~mm}, 5 \mu$. The mobile phase flow rate has been done at $255 \mathrm{~nm}$ in order to obtain enough sensitivity. By using above conditions, we get retention times of Mitomycin and Fluorouracil were about $1.869 \mathrm{~min}$. and $2.750 \mathrm{~min}$ with a tailing factor of 1.05 and 1.11 . The number of theoretical plates for Mitomycin and Fluorouracil was 3624,5748, which indicate the column's successful output the \% RSD for six replicate injections was around $0.17 \%$ (Mitomycin) and $0.50 \%$ (Fluorouracil); the proposed approach suggests that it is extremely precise. According to ICH guidelines, the method established was validated.

There are no UPLC and HPLC methods reported in the literature. So, it is interesting to develop a UPLC method for the estimation of the combined drugs in vitro method.

\section{System suitability}

System suitability parameters have been calculated to check the performance of the system. The parameters can be measured and found to be within the limit, including USP plate count, USP tailing, and percent RSD. Results of system suitability were given in the following table 1 [48].

Table 1: Results of system suitability

\begin{tabular}{lll}
\hline System suitability parameter & Acceptance criteria & Drug name \\
\cline { 2 - 3 } & & Mitomycin \\
\hline USP Plate Count & NLT 2000 & 3628 \\
USP Tailing & NMT 2.0 & 1.02 \\
USP Resolution & NLT 2.0 & - \\
\% RSD & NMT 2.0 & 0.17 \\
\hline
\end{tabular}

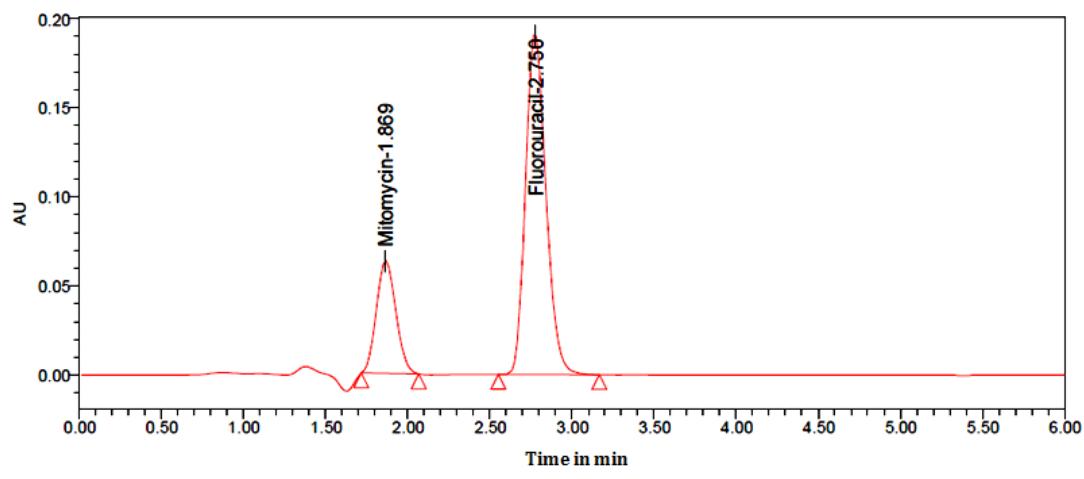

Fig. 2: Chromatogram of system suitability

\section{Specificity}

The capacity to test the analyte unequivocally in the presence of other elements, such as impurities, Excitements that might be assumed in order to be present in the sample solution and norm solution, is specificity.
According to the test method placebo, sample and standard solutions were analyzed individually to examine the interference. The below fig. shows that the active ingredients were well separated from blank and their excipients and there was no interference of placebo with the principal peak. Hence the method is specific. 


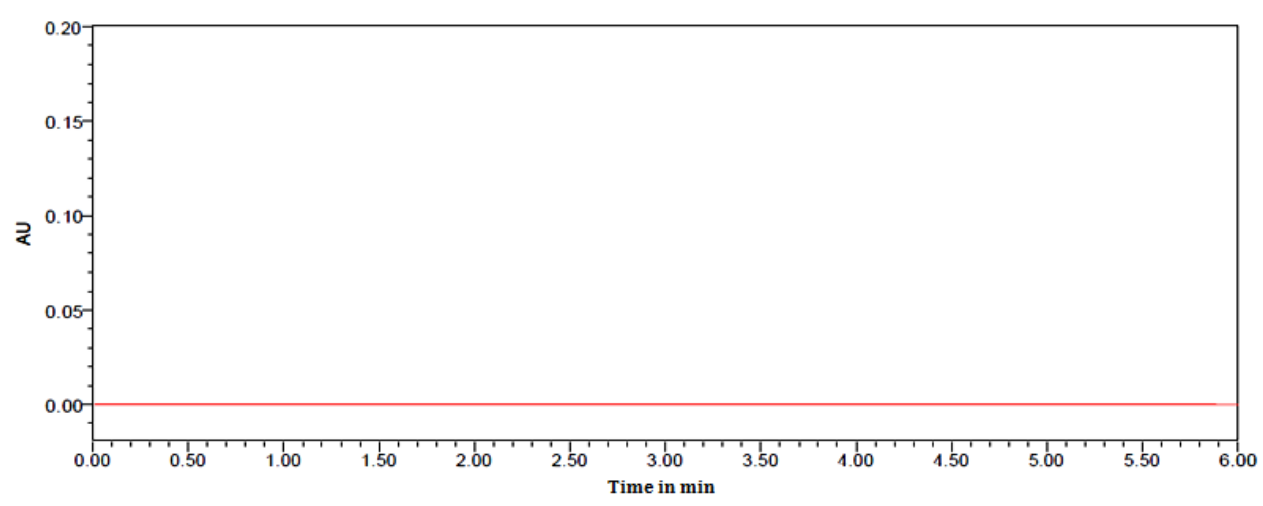

Fig. 3: Chromatogram of blank

Table 2: Linearity of mitomycin and fluorouracil

\begin{tabular}{|c|c|c|c|c|}
\hline S. No. & Conc. $\mu \mathrm{g} / \mathrm{ml}$ & Mitomycin area count & Conc. $\mu \mathrm{g} / \mathrm{ml}$ & Fluorouracil area count \\
\hline 1 & 2.00 & 17504 & 5.00 & 236501 \\
\hline 2 & 5.00 & 45653 & 12.50 & 603257 \\
\hline 3 & 10.00 & 95687 & 25.00 & 1205746 \\
\hline 4 & 20.00 & 191546 & 50.00 & 2451068 \\
\hline 5 & 25.00 & 228167 & 62.50 & 2825715 \\
\hline 6 & 30.00 & 280568 & 75.00 & 3498601 \\
\hline Correl coef & & 0.9996 & & 0.9990 \\
\hline Slope & & 9328.11 & & 46375.47 \\
\hline intercept & & 134.12 & & 22075.56 \\
\hline
\end{tabular}

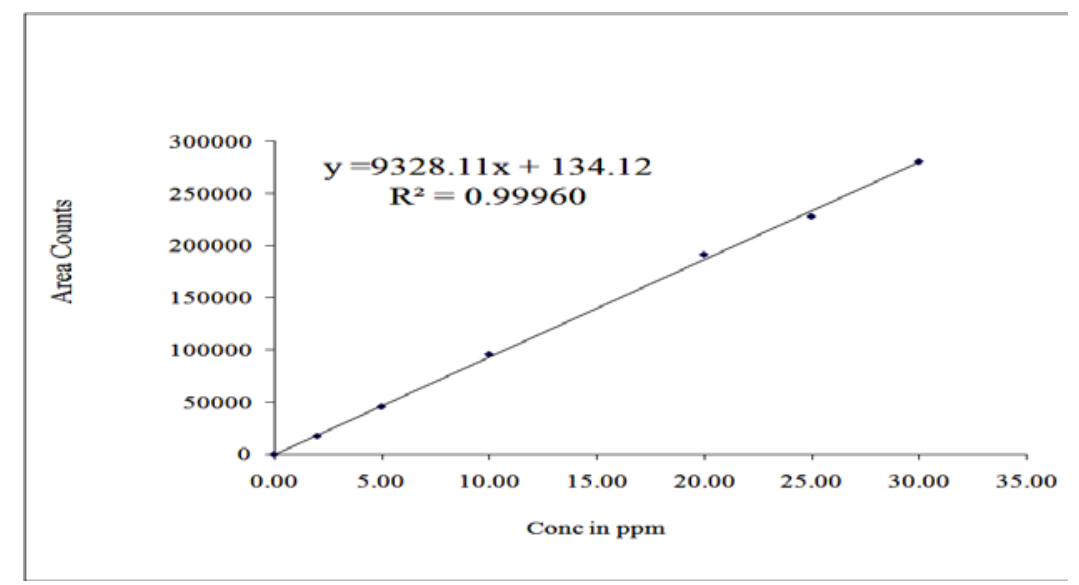

A

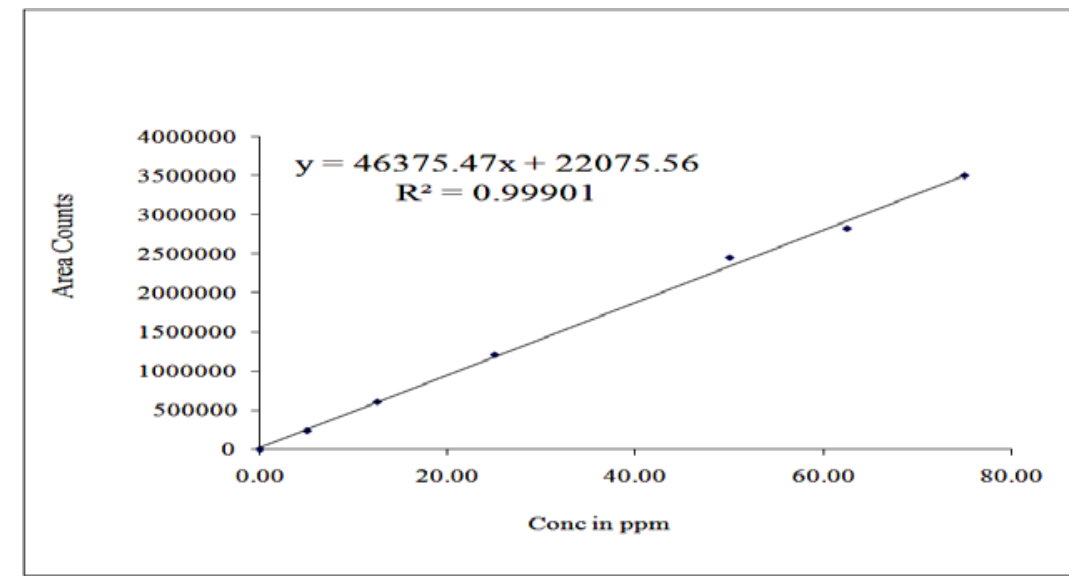

B

Fig. 4: Calibration plots of (A) Mitomycin (B) Fluorouracil 


\section{Linearity}

The area of the linearity peak versus different concentrations has been evaluated for Mitomycin, Fluorouracil, as 10, 25, 50, 100, 125, 150 percent respectively. The linear regression analysis was plotted with the peak area versus concentration data. The correlation coefficients of regression, Percent, y-intercept and slope of the calibration curves were calculated. The correlation coefficients achieved greater than 0.999 for all.

\section{Accuracy}

In this method, Accuracy was conducted in triplicate by analyzing active pharma ingredient sample solution spiked with known amounts of all the impurities at three kinds of concentration levels of 50, 100 and $150 \%$ of each at a specified limit. For all impurities, percentage recoveries were measured and found to be within the limit. The accuracy and reliability of the developed method were established. The percentage recovery values were found to be in the range of $100.13-100.59 \%$ for Mitomycin and $99.81-99.95 \%$ for Fluorouracil. The results are given in table 3, 4 and 5 .

\section{Precision}

The precision of an analytical technique is the degree of closeness of series of measurements derived from multiple homogeneous mixture samplings. The exactness of the process of related substances was performed by injection of six individual injection determinations of Mitomycin (20 ppm) and Fluorouracil (50 ppm).

Table 3: Results of accuracy

\begin{tabular}{llll}
\hline S. No. & \% Level & Mitomycin \% recovery & Fluorouracil \% recovery \\
\hline 1 & 50 & 100.24 & 99.98 \\
2 & 100 & 100.59 & 99.81 \\
3 & 150 & 100.13 & 99.95 \\
mean & & 100.32 & 99.91 \\
SD & & 0.240 & 0.091 \\
\hline
\end{tabular}

Mean+SD $(n=3)$

Table 4: Intraday precision results of mitomycin and fluorouracil

\begin{tabular}{lllllll}
\hline Mitomycin & & & & Fluorouracil & & \\
\hline S. No. & Conc. $(\boldsymbol{\mu g} / \mathbf{m l})$ & Area counts & \% Assay as is & Conc. $(\boldsymbol{\mu g} / \mathbf{m l})$ & Area counts & \% Assay as is \\
\hline 1 & 20 & 191365 & 100 & 50 & 2451991 & 100.2 \\
2 & & 191143 & 99.9 & & 2451387 & 100.1 \\
3 & 191650 & 100.2 & & 2435647 & 99.5 \\
4 & 191554 & 100.1 & & 2458475 & 100.4 \\
5 & 190546 & 99.6 & & 2455305 & 100.3 \\
6 & 193341 & 101 & 0.370 .36 & 2461250 & 100.5 \\
$\%$ RSD & 0.490 .47 & & & & \\
Mean & 100.13 & & & 0.35590 & & \\
SD & 0.47188 & & & & & \\
\hline
\end{tabular}

Mean+SD $(n=6)$

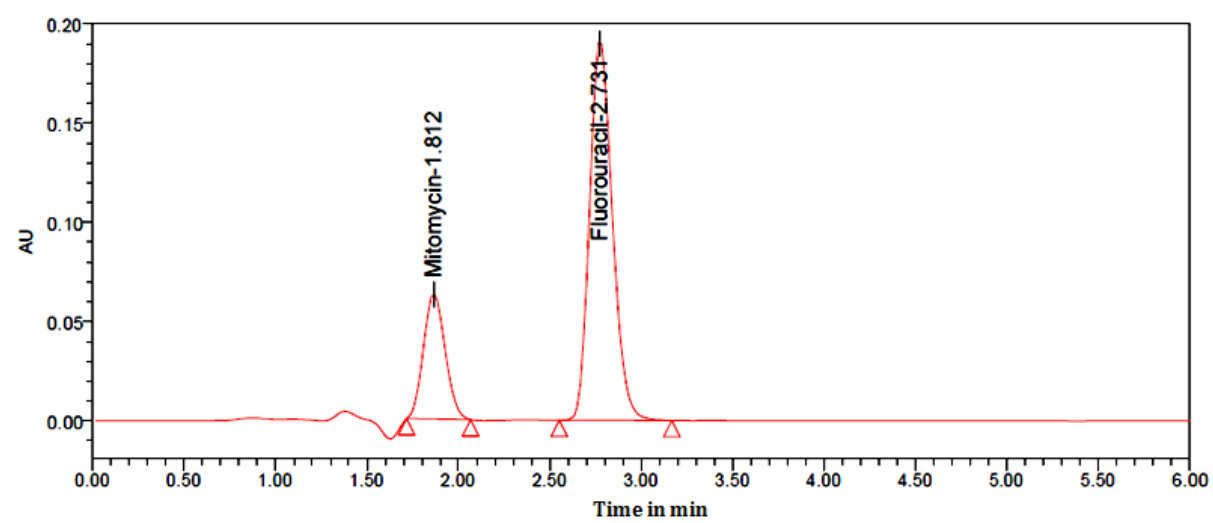

Fig. 5: Chromatogram of sample

\section{Intermediate precision}

Six replicates of the sample solution were studied by various researchers, and on separate days different instruments were tested. The peak regions used to determine to mean percent RSD values have been calculated. The results are given in the following table.

\section{Intraday precision}

Six replicates of a sample solution containing Mitomycin $(20 \mu \mathrm{g} / \mathrm{ml})$ and Fluorouracil $(50 \mu \mathrm{g} / \mathrm{ml})$ were analysed on the same day. Peak areas were calculated, which were used to calculate mean, SD and \% RSD values.

\section{Interday precision}

Six replicates of a sample solution containing Mitomycin $(20 \mu \mathrm{g} / \mathrm{ml})$ and Fluorouracil $(50 \mu \mathrm{g} / \mathrm{ml})$ were analysed on a different day. Peak areas were calculated which were used to calculate mean, SD and \% RSD values. The present method was found to be precise as the RSD values were less than $2 \%$ and also the percentage assay values were close to be $100 \%$. The results are given in table 5 [49]. 
Table 5: Inter-day outcomes of accuracy of mitomycin and fluorouracil

\begin{tabular}{|c|c|c|c|c|c|c|}
\hline \multicolumn{4}{|c|}{ Mitomycin } & \multicolumn{3}{|l|}{ Fluorouracil } \\
\hline S. No. & Conc. $(\mu \mathrm{g} / \mathrm{ml})$ & Area counts & $\%$ assay as is & Conc. $(\mu \mathrm{g} / \mathrm{ml})$ & Area count & $\%$ Assay as is \\
\hline 1 & & 191884 & 100.2 & & 2451206 & 100.1 \\
\hline 2 & 20 & 191327 & 100.0 & 50 & 2451954 & 100.2 \\
\hline 3 & & 191009 & 99.8 & & 2434567 & 99.4 \\
\hline 4 & & 191567 & 100.1 & & 2454877 & 100.3 \\
\hline 5 & & 191256 & 99.9 & & 2448512 & 100 \\
\hline 6 & & 192368 & 100.5 & & 2425457 & 99.1 \\
\hline$\%$ RSD & 0.260 .25 & & & 0.480 .49 & & \\
\hline Mean & 100.08 & & & 99.85 & & \\
\hline SD & 0.24833 & & & 0.48477 & & \\
\hline
\end{tabular}

Mean+SD $(n=6)$

\section{LOD and LOQ}

LOD for LOD and LOQ were calculated separately using the calibration curve process. The LOD and LOQ of the compound were calculated using the developed RP-HPLC method by injecting increasingly lower concentrations of the standard solution. The LOD and LOQ concentrations and their $\mathrm{S} / \mathrm{N}$ values were shown in the following table. The method is validated as per the ICH guidelines [50]. LOD and LOQ results were tabulated in table 6.

Table 6: LOD and LOQ for mitomycin and fluorouracil

\begin{tabular}{|c|c|c|c|c|c|c|c|}
\hline \multicolumn{4}{|l|}{ Mitomycin } & \multicolumn{4}{|l|}{ Fluorouracil } \\
\hline LOD & & LOQ & & LOD & & LOQ & \\
\hline Concentration & $\mathrm{s} / \mathrm{n}$ & Concentration & $\mathrm{s} / \mathrm{n}$ & concentration & $\mathrm{s} / \mathrm{n}$ & Concentration & $\mathrm{s} / \mathrm{n}$ \\
\hline $0.025 \mu \mathrm{g} / \mathrm{ml}$ & 4 & $0.083 \mu \mathrm{g} / \mathrm{ml}$ & 28 & $0.063 \mu \mathrm{g} / \mathrm{ml}$ & 7 & $0.208 \mu \mathrm{g} / \mathrm{ml}$ & 25 \\
\hline
\end{tabular}

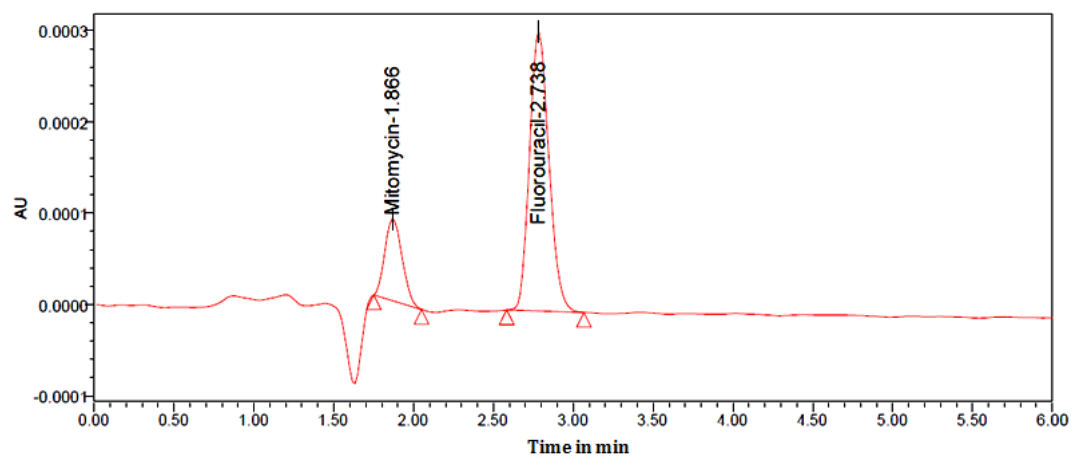

A

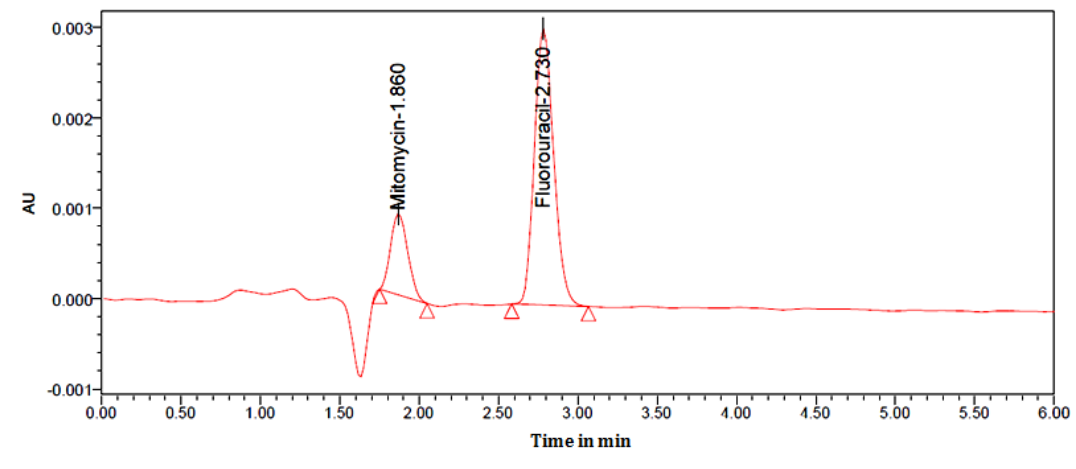

B

Fig. 6: Chromatogram of (A) LOD and (B) LOQ

Table 7: Robustness data of mitomycin and fluorouracil

\begin{tabular}{lll}
\hline Parameter name & \% RSD & Fluorouracil \\
\cline { 2 - 3 } & Mitomycin & 0.26 \\
\hline Flow minus $(0.8 \mathrm{ml} / \mathrm{min})$ & 0.32 & 0.40 \\
Flow plus $(1.2 \mathrm{ml} / \mathrm{min})$ & 0.24 & 0.68 \\
Organic minus $(-10 \%)$ & 0.21 & 0.85 \\
Organic plus $(+10 \%)$ & 0.10 & \\
\hline
\end{tabular}




\section{Robustness}

The conditions of the experiment were designed to test the robustness of the established system intentionally altered, such as flow rate, mobile phase in organic percentage in all these varied conditions. The resolution between active Pharma ingredients from impurities was not significantly affected and there was no significant influence on the time of retention, plate count and tailing factor. Hence this method was robust [51].

\section{Stability}

The standard and sample solution was kept at room temperature and at $2-8{ }^{\circ} \mathrm{C}$ up to $24 \mathrm{~h}$. Then these solutions were pumped into the device and calculate the $\%$ of deviation from initial to $24 \mathrm{~h}$ [52]. There was no significant deviation observed and confirmed that the solutions were stable up to $24 \mathrm{~h}$ percentage of the assay was not quite $2 \%$. There is no effect in storage conditions for Mitomycin and Fluorouracil drugs.

\section{Degradation studies}

The Fluorouracil and Mitomycin sample was subjected into various forced degradation conditions to effect partial degradation of the drug. Studies of forced degradation have carried out to find out that the method is suitable for products of degradation $[53,54]$. In addition, the studies provide details about the conditions during which the drug is unstable in order that the measures are often taken during formulation to avoid potential instabilities.

\section{Acid degradation}

$1 \mathrm{ml}$ of standard stock solution passed on to a volumetric flask of 10 $\mathrm{ml}, 1 \mathrm{ml}$ of $1 \mathrm{~N} \mathrm{HCl}$ and leaves it for $15 \mathrm{~min}$. After $15 \mathrm{~min}$ add $1 \mathrm{ml}$ of $1 \mathrm{~N} \mathrm{NaOH}$ and made up to the mark with diluents.

\section{Alkali degradation}

$1 \mathrm{ml}$ of standard stock solution was put in a $10 \mathrm{ml}$ volumetric flask and add $1 \mathrm{ml}$ of $1 \mathrm{~N} \mathrm{NaOH}$ and leave it for $15 \mathrm{~min}$. After 15 min add 1 $\mathrm{ml}$ of $1 \mathrm{~N} \mathrm{HCl}$ and made up to the mark with diluents.

\section{Peroxide degradation}

In a $10 \mathrm{ml}$ volumetric flask, $1 \mathrm{ml}$ of standard stock solution was transferred, add $0.3 \mathrm{ml}$ of $30 \%$ hydrogen peroxide and made up to the mark with diluents.

\section{Reduction degradation}

In a $10 \mathrm{ml}$ volumetric flask, $1 \mathrm{ml}$ standard stock solution was transferred and add $1 \mathrm{ml}$ of $30 \%$ sodium bi sulphate solution and made up to the mark with diluents.

Table 8: Stability results of mitomycin and fluorouracil at RT

\begin{tabular}{lllll}
\hline Stability & Mitomycin & Fluorouracil \\
\cline { 2 - 5 } & Purity & \% of deviation & Purity \\
\hline Initial & 100 & 0.00 & 100 & \% of deviation \\
$6 \mathrm{H}$ & 99.9 & -0.10 & 99.9 & 0.00 \\
$12 \mathrm{H}$ & 99.8 & -0.20 & 99.2 & -0.10 \\
$18 \mathrm{H}$ & 99.7 & -0.30 & 98.8 & -0.80 \\
$24 \mathrm{H}$ & 99.6 & -0.40 & 98.4 & -1.20 \\
\hline
\end{tabular}

Table 9: Stability results of mitomycin and fluorouracil at $2-8{ }^{\circ} \mathrm{C}$

\begin{tabular}{|c|c|c|c|c|}
\hline \multirow[t]{2}{*}{ Stability } & \multicolumn{2}{|c|}{ Mitomycin } & \multicolumn{2}{|c|}{ Fluorouracil } \\
\hline & Purity & $\%$ of deviation & Purity & $\%$ of deviation \\
\hline Initial & 100.2 & 0.00 & 100 & 0.00 \\
\hline $6 \mathrm{H}$ & 100.1 & -0.10 & 99.8 & -0.20 \\
\hline $12 \mathrm{H}$ & 99.9 & -0.30 & 99.3 & -0.70 \\
\hline $18 \mathrm{H}$ & 99.8 & -0.40 & 98.9 & -1.10 \\
\hline $24 \mathrm{H}$ & 99.7 & -0.50 & 98.4 & -1.60 \\
\hline
\end{tabular}

Table 10: Forced degradation results of mitomycin and fluorouracil

\begin{tabular}{llll}
\hline Degradation condition & Mitomycin & \multicolumn{2}{c}{ Fluorouracil } \\
\cline { 2 - 4 } & \% assay & \% Deg & \% assay \\
\hline Acid degradation & 84.7 & 15.2 & 83.2 \\
Alkali degradation & 86.9 & 13.1 & 16.5 \\
Peroxide degradation & 86.3 & 13.7 & 16.7 \\
Reduction degradation & 88.5 & 11.5 & 87.7 \\
Thermal degradation & 89.1 & 12.3 & 85.4 \\
\hline
\end{tabular}

\section{Thermal degradation}

The standard solution was set in an oven at $105^{\circ}$ for $6 \mathrm{~h}$. The resultant solution was injected into HPLC.

\section{CONCLUSION}

We present in this article simple, selective, validated and welldefined stability that shows gradient RP-UPLC methodology for the quantitative determination of Mitomycin and Fluorouracil. All the products of degradation formed during the stress conditions and the related active pharma ingredients are well separated and peaks were well resolved from each other and separate with an appropriate retention time, indicating that the proposed method to be fast, simple, feasible and affordable in assay condition. Therefore the developed method during stability tests, it can be used for routine analysis of production samples and to verify the quality of drug samples during stability studies.

\section{ACKNOWLEDGEMENT}

The authors are grateful to the management of Shree Icon Pharmaceutical Laboratory, Labbipeta, Vijayawada, Andhra Pradesh, India, for providing the necessary facilities and assistance in carrying out this study.

\section{FUNDING}

Nil

\section{AUTHORS CONTRIBUTIONS}

All authors have contributed equally. 


\section{CONFLICTS OF INTERESTS}

Declared none

\section{REFERENCES}

1. Balitz DM, Bush JA, Bradner WT, Doyle TW, O'Herron FA, Nettleton DE. Isolation of lavendamycin, a new antibiotic from streptomyces lavendulae. J Antibiot 1982;35:259-65.

2. Hosted TJ, Wang T, Horan AC. Characterization of the streptomyces lavendulae IMRU 3455 linear plasmid pSLV45. Microbiology 2004;150:1819-27.

3. Addison K, Braden JH, Cupp JE, Emmert D, Hall LA, Hall T, et al. Update: guidelines for defining the legal health record fordisclosure purposes. J AHIMA 2005;76:64A-64G.

4. Ensminger AW. Legionella pneumophila, armed to the hilt: justifying the largest arsenal of effectors in the bacterial world. Curr Opin Microbiol 2016;29:74-80.

5. Cianciotto, Nicholas P. An update on iron acquisition by legionella pneumophila: new pathways for siderophore uptake and ferric iron reduction. Future Microbiol 2015;10:841-51.

6. Best, Ashley, Kwaik, Yousef Abu. Evolution of the arsenal of legionella pneumophila effectors to modulate protist hosts. mBio 2018;9:1313.

7. Charpentier X, Kay E, Schneider D, Shuman HA. Antibiotics and UV radiation induce competence for natural transformation in legionella pneumophila. J Bacteriol 2011;193:1114-21.

8. Saito Y, Taguchi H, Akamatsu T. DNA taken into bacillus subtilis competent cells by lysed-protoplast transformation is not ssDNA but dsDNA. J Biosci Bioeng 2006;10:334-9.

9. Poyedinok NL, Blume YaB. Advances, problems, and prospects of genetic transformation of fungi. Cytol Genetics 2018;52:139-54.

10. Dudzic JP, Hanson MA, Iatsenko I, Kondo S, Lemaitre B. more than black or white: melanization and toll share regulatory serine proteases in drosophila. Cell Reports 2019;27:1050-61.

11. Xiao C, Qiu S, Robertson RM. The white gene controls copulation success in Drosophila melanogaster. Sci Rep 2017;7:7712.

12. Brunet S, Verlhac MH. Positioning to get out of meiosis: the asymmetry of division. Human Reproduction Update 2010;17:68-75.

13. Brar GA, Yassour M, Friedman N, Regev A, Ingolia NT, Weissman JS. High-resolution view of the yeast meiotic program revealed by ribosome profiling. Science 2012;335:552-7.

14. Schewe MJ, Suzuki DT, Erasmus U. The genetic effects of mitomycin C in drosophila melanogaster. II. Induced meiotic recombination. Mutat Res 1971;12:269-79.

15. Durvasula A, Fulgione A, Gutaker RM, Alacakaptan SI, Flood PJ, Neto C, et al. Arabidopsis thaliana. PNAS 2017;114:5213-8.

16. Fulgione A, Hancock AM. Archaic lineages broaden our view on the history of Arabidopsis thaliana. New Phytol 2018;219:1194-8.

17. Kalatova B, Jesenska R, Hlinka D, Dudas M. Tripolar mitosis in human cells and embryos: occurrence, pathophysiology and medical implications. Acta Histochem 2015;117:111-25.

18. Wilkins AS, Holliday R. The evolution of meiosis from mitosis. Genetics 2009;181:3-12.

19. Bleuyard JY, Gallego ME, Savigny F, White CI. Differing requirements for the Arabidopsis Rad51 paralogs in meiosis and DNA repair. Plant J 2005;41:533-45.

20. Feng Jie, Shi, Wanliang, Zhang, Shuo, Zhang, Ying. Identification of new compounds with high activity against stationary phase borrelia burgdorferi from the NCI compound collection. Emerg Microbes Infect 2015;4:e31.

21. Sharma, Bijaya, Brown, Autumn V, Matluck, Nicole E, et al. borrelia burgdorferi, the causative agent of lyme disease, forms drug-tolerant persister cells. Antimicrob Agents Chemother 2015;59:864-15.

22. Rustagi T, Aslanian HR, Laine L. Treatment of refractory gastrointestinal strictures with mitomycin c: a systematic review. J Clin Gastroenterol 2015;49:837-47.

23. Abourne E, Clarke JC, Schlottmann PG, Evans JR. Mitomycin C versus 5-fluorouracil for wound healing in glaucoma surgery (PDF). Cochrane Database Syst Rev 2015;11:CD006259.

24. Majmudar, Parag A, Forstot, S Lance, Dennis, Richard F, et al. Topical Mitomycin-C for subepithelial fibrosis after refractive corneal surgery. Ophthalmology 2000;107:89-94.
25. heng SM, Feng YF, Xu L, Li Y, Huang JH. Efficacy of mitomycin c in endoscopic dacryocystorhinostomy: a systematic review and meta-analysis. PLoS One 2013;8:e62737.

26. Holick MF. Vitamin D, sunlight and cancer connection. Anticancer Agents Med Chem 2013;13:70-82.

27. Emilsson L, Holme O, Bretthauer M, Cook NR, Buring JE, Løberg $\mathrm{M}$, et al. Systematic review with meta-analysis: the comparative effectiveness of aspirin vs. screening for colorectal cancer prevention. Aliment Pharmacol Ther 2017;45:193-204.

28. Sultan, Rizwan, Haider, Zishan, Chawla, Tabish Umer. Diagnostic accuracy of CT scan in staging resectable esophageal cancer. JPMA. J Pak Med Assoc 2016;66:90-2.

29. Polistina F, Di Natale G, Bonciarelli G, Ambrosino G, Frego M. Neoadjuvant strategies for pancreatic cancer. World J Gastroenterol 2014;20:9374-83.

30. Burstein HJ, Temin S, Anderson H, Buchholz TA, Davidson NE, Gelmon KE, et al. Adjuvant endocrine therapy for women with hormone receptor-positive breast cancer: American society of clinical oncology clinical practice guideline focused update. J Clin Oncol 2014;32:2255-69.

31. Luhn P, Walker J, Schiffman M, Zuna RE, Dunn ST, Gold MA, et al. The role of co-factors in the progression from human papillomavirus infection to cervical cancer. Gynecol Oncol 2013;128:265-70.

32. Askew DA, Mickan SM, Soyer HP, Wilkinson D. Effectiveness of 5fluorouracil treatment for actinic keratosis--a systematic review of randomized controlled trials. Int J Dermatol 2009;48:453-63.

33. Fusco N, Lopez G, Gianelli U. Basal-cell carcinoma and seborrheic keratosis: when opposites attract. Int J Surg Pathol 2015;23:464.

34. Moore AY. Clinical applications for topical 5-fluorouracil in the treatment of dermatological disorders. J Dermatol Treat 2009;20:328-35.

35. Matera, Carlo, Gomila, Alexandre MJ, Camarero. Photoswitchable Antimetabolite for Targeted Photoactivated Chemotherapy. J Am Chem Soc 2018;140:15764-73.

36. Peters GJ, Backus HH, Freemantle S, Van Triest B, Codacci Pisanelli G. Induction of thymidylate synthase as a 5fluorouracil resistance mechanism. Biochim Biophys Acta 2002;1587:194-205.

37. World Health Organization. World Health Organization model list of essential medicines: 21st list 2019. Geneva: World Health Organization; 2019.

38. Bethune G, Campbell J, Rocker A, Bell D, Rendon R, Merrimen J. Clinical and pathologic factors of prognostic significance in penile squamous cell carcinoma in a North American population. Urology 2012;79:1092-7.

39. Wang X, Khan R, Coleman A. Device-modified trabeculectomy for glaucoma. Cochrane Database Syst Rev 2015;12:CD010472.

40. Pardianto G. Recent awareness and consideration of intraocular pressure fluctuation during eye surgery. J Cataract Refract Surg 2015;41:695.

41. Cijo M Xavier, Kanakapura Basavaiah. RP-UPLC development and validation of metformin hydrochloride in pure drug and pharmaceutical formulations. World J Pharm Pharm Sci 2015;4:1649-68.

42. Shalini K, Ilango K. Development, evaluation and RP-HPLC method for simultaneous estimation of quercetin, ellagic acid and kaempferol in a poly herbal formulation. Int J Appl Pharm 2021;13:183-92.

43. Mohinish Sahai, Devanna N. Validated stability indicating HPLC approach for quantifying tricholine citrate and ciproheptadine simultaneously in syrup forms. Int J Appl Pharm 2021;13:207-13.

44. Sri Girija K, Bikshal Babu K, Venkateswara Rao A. A new high performance liquid chromatography method for the separation and simultaneous quantification of Eptifibatide and its impurities in pharmaceutical injection formulation. Int J Appl Pharm 2021;13:165-72.

45. V L N Balaji Gupta T, Venkateswara Rao B, Kishore Babu B. RPHPLC (stability-indicating) based assay method for the simultaneous estimation of doravirine, tenofovir disoproxil fumarate and lamivudine. Int J Appl Pharm 2021;13:153-9.

46. Murali Krishnam Raju P, Venkata Narayana B, Shyamala P, Srinivasu K, H S N Raju D. A validated RP-HPLC method for 
impurity profiling of sodium nitroprusside in injection dosage form. Int J Appl Pharm 2021;13:160-9.

47. Sanathoiba Singha L, Srinivasa Rao T. Development and validation of an RP-HPLC method for the determination of ulipristal acetate in pharmaceutical dosage form. Asian J Pharm Clin Res 2021;14:83-9.

48. Asha Eluru, Surendra Babu K. A study of method development, validation and forced degradation for simultaneous quantification of povidone-iodine and ornidazole in bulk and pharmaceutical dosage form by using RP-HPLC. IJPSR 2021;12:1217-22.

49. Malathi S, Devakumar D. Development and validation of RPHPLC method for the estimation of escitalopram oxalate and flupentixol dihydrochloride in combined dosage form and plasma. Int J Pharm Pharm Sci 2021;13:61-6.

50. Rafi S, Rambabu K. Stability indicating validated HPLC method for the determination of aceclofenac and misoprostol in bulk and pharmaceutical formulation. Int J Res Pharm Sci 2020;11:7848-53.

51. Raviteja G, Rambabu K. A study of development and validation of a method for simultaneous estimation of cidofovir and famciclovir using RP-HPLC. Int J Res Pharm Sci 2020;11:7878-84.

52. Sruthi A, Uttam Prasad P. Stability indicating method development and validation of fimasartan by reverse phase high-performance liquid chromatography in bulk and pharmaceutical dosage form. Asian J Pharm Clin Res 2021;14:138-46.

53. Mohinish Sahai, N Devanna. Validated stability indicating HPLC approach for quantifying tricholine citrate and cyproheptadine simultaneously in syrup forms. Int J Appl Pharm 2021;13:207-13.

54. Abdul Raziq, Syed Umer Jan. Relative comparison of stability and degradation of methylcobalamin tablets of different brands at different storage settings. Int J Appl Pharm 2021;13:171-5. 